\title{
Manajemen Konflik Dalam Meningkatkan Kedisiplinan Guru (Studi Kebijakan Di Smp Al-Kautsar Tanjungpinang Kepulauan Riau)
}

\author{
Ainur Rofiq \\ Pascasarjana UIN Sunan Kalijaga Yokyakarta \\ Email : ainurrofiq293@yahoo.com
}

\begin{abstract}
The backeground of this research that conflict is a natural moment and we usually find of our life, especially in the education institution. Conflict can't be avoided. Conflict in the junior high school of Al-Kautsar involves between beadmaster and teachers. It happens because of many policy of headmaster and disciplineless of teachers. There are many method to manage and to solve conflict. This research is to describe conflict and conflict management of headmaster leadership in the junior bigh school of Al-Kautsar. The kind of this research is field reseach with qualitative research method. The method of data's analysing uses milles and buberman. The method to find data's is observation, deepth interview and documentation. Then the technic to crosscheck about validity of data's is triangulation technic and source, validity, and normality. The source of research data is director, headmaster, vice head and teachers in the junior high school of Al-Kautsar. Technic of analysing data's for qualitative is reduction display, evaluation and data's verification. This result of research shows that: First: conflict that happens between headmaster and teachers in the junior high school is caused by many method and ego of headmaster and teachers. Second: the awareness of discipline of the teachers is still low, especially to understand the rule that has been decided. Third: it is very important to increase coordination and socialization between headmaster and teachers to conflict management at Al-Kautsar's junior high school so that there are much perception and goal in order to increace quality of education. Actually headmaster and teachers are one of success determining in the education institution, especially at school. Conflict can be solved or managed to be a productive thing. It must be managed by manager or leader of education organization and it can be mediated by expert of conflict management.
\end{abstract}

Key words : Conflict Management, Policy, Discipline, Education Institution

Nidhomul Haq: Jurnal Manajemen Pendidikan Islam ISSN: 2503-1481 Hal: 76-97 


\section{A. PENDAHULUAN}

Di era global dengan ditandainya kemajuan di bidang sains dan teknologi yang semakin pesat, lebih lagi dengan dibukanya kran memasuki dunia digital, interaksi sosial di antara manusia sebagai makhluk sosial menjadi lebih mudah. Dalam kapasitasnya sebagai bagian dalam bermasyarakat, manusia tidak bisa terlepas dari berbagai permasalahan. Berbagai perbedaan pandangan, nilai, dan tujuan sangat rentan memantik timbulnya konflik.

Perbedaan pandangan antar perorangan juga dapat mengakibatkan konflik. Suatu konflik bukanlah harus kita hindari, akan tetapi bagaimana kita dapat mengelola konflik tersebut sehingga dapat menjadi suatu kerjasama yang produktif. ${ }^{1}$ Pandangan para ahli manajemen bervariasi dalam memberikan penjelasan mengenai konflik. Para ahli manajemen tradisional yang berkembang tahun 1940-an, menyatakan bahwa konflik adalah sesuatu yang harus dihindari, ditolak, tidak produktif, destruktif, dan bernuansa negatif. Namun dalam perkembangannya, para ahli manajemen di era modern memberikan pengertian yang lebih luas dan objektif. Konflik sendiri merupakan proses alamiah yang terjadi dalam setiap organisasi sekaligus merupakan organisasi dan individu selalu terjadi konflik. ${ }^{2}$ Konflik dianggap sesuatu yang wajar dan alamiah, bahkan bisa dikelola menjadi sesuatu yang positif dan konstruktif jika dikelola

${ }^{1}$ Fatah Syukur, Manajemen Pendidikan Berbasis Pada Madrasah, (Semarang: PT Pustaka Rizki Putra, 2011), hlm. 160.

2 Husaini Usman, Manajemen: Teori, Praktik, dan Riset Pendidikan,(Jakarta: Remaja Rosdakarya, 2014), hlm. 505. dengan baik dan hati-hati, karena jika melewati batas akan berakibat fatal. ${ }^{3}$ Konflik sering diartikan proses pertentangan yang diekspresikan di antara dua belah pihak atau lebih yang saling tergantung mengenai objek konflik, menggunakan pola perilaku dan interaksi konflik yang menghasilkan konflik. ${ }^{4}$

$$
\text { Menurut Kartini Kartono }
$$

sebagaimana dikutip oleh Hendyat Soetopo, arti konflik mengacu pada semua benturan, tabrakan, ketidaksesuaian, ketidakserasian, pertentangan, perkelahian, oposisi, dan interaksi-interaksi yang antagonis bertentangan. ${ }^{5}$ Secara fitrah manusia dilahirkan dalam karakter dan perilaku yang berbeda-beda. Hal ini yang menyebabkan terjadinya konflik antara individu dalam sebuah organisasi, tak terkecuali di lembaga pendidikan. Perbedaan pendapat, salah paham, salah satu pihak merasa dirugikan, perasaan yang terlalu sensitif, perilaku yang tidak menyenangkan, konflik yang disebabkan struktur adalah beberapa penyebab terjadinya konflik. ${ }^{6}$

Konflik di SMP Al-Kautsar Tanjungpinang karena beberapa kebijakan kepala sekolah tidak sesuai dengan para pendidik. Komunikasi yang terjalin antara kepala sekolah dan para pendidik hanya

${ }^{3}$ E. Mulyasa. Menjadi Kepala Sekolah Profesional: dalam Konteks menyukseskan MBS dan KBK, cet. ke-6, ( Bandung: PT Remaja Rosdakarya, 2005), hlm. 238 .

4 Wirawan, Konflik Dan Manajemen Konflik: Teori, Aplikasi, dan Penelitian, (Jakarta: Salemba Humanika, 2013), hlm. 5.

5 Hendyat Soetopo, Perilaku Organisasi:Teori dan Praktik Dibidang Pendidikan, (Bandung: Rosdakarya dan UNM,2012), hlm. 267.

${ }^{6}$ Moh Pabundu Tika, Budaya Organisasi dan Peningkatan Kinerja Perusahaan, (Jakarta: Bumi Aksara, 2006), hlm. 85 
sebatas teman kerja. Hubungan antara kepala sekolah dan bawahannya juga kurang baik dalam kegiatan-kegiatan yang menyangkut tugas-tugas internal organisasi. Dalam melakukan kegiatan baik yang berkaitan dengan tugas-tugas pendidikan maupun pembelajaran, antara kepala sekolah dan bawahannya sering tidak kompak dan terkesan berjalan sendiri-sendiri. Ego antara kepala sekolah dan para pendidik juga faktor terjadinya konflik. Hal ini bisa dilihat dari tidak adanya saling take and give dalam mengerjakan tugas-tugas kependidikan, baik tugas yang diberikan kepada para pendidik maupun kepala sekolah. Beberapa tugas para pendidik seperti membuat rpp, silabus, dan lainnya sering tidak diperiksa atau dikoreksi kepala sekolah, begitu juga beberapa pendidik senior merasa lebih berpengalaman dari kepala sekolah. Dalam menegur bawahannya ketika melakukan kesalahan terkait kedisiplinan para pendidik, kepala sekolah sering menggunakan bahasa dengan nada tinggi dan kurang baik. Menurut Ahmad Muslim dalam jurnalnya, bahwa penyebab terjadinya konflik antara kepala sekolah dengan bawahan dikarenakan perbedaan tujuan, merasa hebat, perbedaan pemahaman, ungkapan kata-kata yang kasar, ego yang tinggi, perasaan tersinggung, merasa diri lebih tinggi, ketidakpuasan terhadap kebijakan kepala sekolah, keterlambatan memasukkan Rpp, silabus, dan materi ajar kepada kepala sekolah. ${ }^{7}$

Menurut Irham Fahmi, faktor yang menyebabkan konflik antara kepala sekolah dengan bawahannya disebabkan kurangnya komunikasi, pengambilan keputusan secara

${ }^{7}$ Ahmad Muslim, "Manajemen Konflik Interpersonal di Sekolah", dalam Jurnal Paedogogy, Fakultas Ilmu Pendidikan IKIP Mataram, Vol 1, Nomor 2, Oktober 2014, hlm. 5. sepihak, dan ego masing-masing individu. ${ }^{8}$ Ketika konflik adalah suatu hal yang tidak dapat dihindari, terlebih dalam dunia pendidikan, maka peran atau pendekatan bagi seorang manager/kepala sekolah dengan memanfaatkan konflik sebaik mungkin, hingga ia efektif dan tepat untuk mencapai sasaran-sasaran yang diinginkan. ${ }^{9}$ Kepala sekolah juga harus mampu mengelola berbagai konflik yang ada dalam institusi pendidikan dengan berbagai strategi manajemen konflik, yang meliputi pemahaman tentang teori-teori konflik, metode pendekatan, bentuk-bentuk konflik, sumber konflik, pengelolaan konflik, konsensus, dan resolusi konflik. ${ }^{10}$

Artikel ini membahas tentang konflik yang terjadi di SMP Al-Kautsar Tanjungpinang dalam menentukan sebuah kebijakan, mengambil sebuah keputusan yang dilakukan kepala sekolah, maupun dalam masalah kedisiplinan pendidik. Secara spesifik, penelitian ini difokuskan untuk meneliti penyebab, jenis, pihak-pihak yang berkonflik, dan resolusi konflik antara kepala sekolah dan para pendidik di SMP Al-Kautsar Tanjungpinang .

Menurut Bahrun, salah seorang pendidik di SMP Al-Kautsar menjelaskan bahwa konflik yang sering terjadi berkaitan dengan masalah kebijakan, sering melakukan kebijakan sendiri tanpa memberitahukan terlebih dahulu pada pendidik dan karyawan. Bahrun juga menerangkan bahwa konflik terjadi karena sikap ego dari kepala sekolah dan para pendidik yang tiada kunjung berakhir. Di samping itu juga kepala sekolah

\footnotetext{
${ }^{8}$ Irham Fahmi, Perilaku Organisasi Teori, Aplikasi dan Kasus..., hlm. 73.

${ }^{9}$ Winardi, Manajemen Konflik: Konflik Perubahan dan Pengembangan, (Bandung: Mandar Maju, 1994), hlm. 1.

10 Edi Santosa, Lilin Budiati, Manajemen Konflik, (Tangerang: Universitas Terbuka, 2014), hlm. 2.
} 
sering mengambil alih sendiri kegiatankegiatan tanpa berkoordinasi dan berkomunikasi terlebih dahulu dengan para pendidik. ${ }^{11}$ Menurut Sudarwan Danim dan Suparno, kemampuan berkomunikasi harus dimiliki kepala sekolah sebagai salah satu kompetensi yang harus dikuasai dan aktif berkomunikasi dengan seluruh anggota komunitas sekolah. ${ }^{12}$

Dalam dunia pendidikan, kedisiplinan pendidik merupakan hal yang sangat penting demi berjalannya proses belajar mengajar. Sedangkan salah satu faktor yang juga dapat menimbulkan konflik di antara pelaku pendidikan adalah sikap kurang disiplin. Kedisiplinan pendidik adalah sikap penuh kerelaan dalam mematuhi semua aturan dan norma yang ada dalam menjalankan tugasnya sebagai bentuk tanggung jawabnya. Sebagai pendidik, seorang guru harus memiliki kesadaran atau merasa mempunyai tanggung jawab untuk mendidik. ${ }^{13}$ Kedisiplinan pendidik juga melekat pada pendidik yang berkaitan dengan dimensi waktu. Seorang pendidik dikatakan disiplin manakala ia dapat menepati semua jadwal atau waktu yang direncanakan. ${ }^{14}$ Bagi pendidik yang disiplin, karena sudah menyatu dalam dirinya, maka disiplin bukan merupakan beban, namun sebaliknya membebani dirinya bila tidak berbuat disiplin. ${ }^{15}$

11 Wawancara dengan Bahrun, pendidik di SMP Al-Kautsar Tanjungpinang, tanggal 4 Pebruari 2017.

12 Sudarwan Danim, Suparno, Manajemen Kepemimpinan dan Kepemimpinan Transformasional Kekepalasekolahan: Visi dan Strategi Sukses Era Teknologi, Situasi Krisis, dan Internasionalisasi Pendidikan, (Jakarta: Jakarta: PT Rineka Cipta, 2009), hlm. 16.

${ }^{13}$ Hanatidah Altar, "Upaya Meningkatkan

Kedisiplinan Guru dalam Kehadiran di Kelas Melalui Keteladanan", dalam Jurnal Bionature, Vol.15, Nomor 1, April 2014, hlm. 17.

${ }^{14}$ Sukarsih, "Meningkatkan Kedisiplinan Guru SMPN 8 Bontang" dalam Jurnal Ilmu Pendidikan,Cendikia, Vol.9, Nomor 1, April 2015, hlm. 3.

${ }^{15}$ Sri Rahayu, "Kepemimpinan Sekolah dan Kedisiplinan Guru SMPN Kota Surakarta", dalam
Kedisiplinan pendidik di SMP AlKautsar masih harus perlu dievaluasi dan dibenahi. Menurut Ridwan, salah satu pendidik di SMP Al-Kautsar, mengatakan salah satu faktor yang menyebabkan kurang disiplinnya para pendidik disebabkan kurangnya kesadaran dari para pendidik pada tata tertib sekolah. ${ }^{16}$ Peraturan yang sudah ditetapkan oleh yayasan, baik yang berkaitan dengan proses pembelajaran maupun yang bersifat sustantif masih sering terabaikan oleh para pendidik. Datang terlambat ketika mengajar, sebagian pendidik laki-laki terkadang memakai sandal dalam proses belajar mengajar, adalah sebagai contoh kurangnya disiplin pada beberapa pendidik dalam mematuhi peraturan yang telah ditetapkan. Usaha agar kedisiplinan pendidik lebih meningkat yaitu dengan memperhatikan kesejahteraan pendidik, memberikan pelatihan kepada para pendidik, memberikan banyak kesempatan kepada para pendidik untuk menyampaikan aspirasi mereka melalui pendapat, saran dan kritik yang sifatnya membangun dan demi kemajuan sekolah, melibatkan pendidik dalam pengambilan keputusan yang berkaitan dengan pelaksanaan tugas demi kepentingan sekolah agar mampu membangun sekolah ke arah yang lebih baik. ${ }^{17}$

SMP Al-Kautsar adalah setingkat sekolah menengah pertama yang terletak di wilayah Tanjungpinang Timur Kota Tanjungpinang. Dalam perkembangannya, SMP Al-Kautsar juga tidak luput dari berbagai permasalahan atau konflik yang terjadi di internal pendidikan tersebut. Hal ini bisa dilihat dari kurang harmonisnya

Jurnal Manajemen Pendidikan, Magister Manajemen Pendidikan UMS, Vol.9, Nomor.2, Juli 2014, hlm. 100. ${ }^{16}$ Wawancara dengan M. Ridwan, pendidik di SMP Al-Kautsar Tanjungpinang, tanggal 20 Pebruari 2018.

${ }^{17}$ Budi Sri Supeni, "Pengaruh TQM dan Kedisiplinan Guru" dalam Jurnal Akuntasi dan Ilmu Pendidikan, Vol.3, Nomor 2, Oktober 2014, hlm. 80. 
hubungan antara kepala sekolah dengan para pendidik dan keluarnya beberapa pendidik dari grup WhatsApp. Kurang harmonisnya hubungan antara kepala sekolah dan para pendidik kalau tidak cepat ditanggapi dengan baik, maka akan terjadi konflik yang berkepanjangan dan akan menjadi semakin kompleks. Berangkat dari realitas yang ada, maka penulis sangat tertarik untuk melakukan penelitian yang terkait dengan judul "Manajemen Konflik dalam Meningkatkan Kedisiplinan Guru (Studi Kebijakan di SMP Al-Kautsar Tanjungpinang Kepulauan Riau)"

\section{B. FOKUS PENELITIAN}

Penelitian ini membahas tentang konflik kepala sekolah di SMP Al-Kautsar Tanjungpinang dalam menentukan sebuah kebijakan, mengambil sebuah keputusan, maupun dalam masalah kedisiplinan para pendidik. Menurut Bahrun, salah seorang pendidik di SMP Al-Kautsar menjelaskan bahwa konflik yang sering terjadi berkaitan dengan masalah kebijakan, sering melakukan kebijakan sendiri tanpa memberitahukan terlebih dahulu pada pendidik dan karyawan. Bahrun juga menerangkan bahwa konflik terjadi karena sikap ego dari kepala sekolah dan para pendidik yang tiada kunjung berakhir. Di samping itu juga kepala sekolah sering mengambil alih sendiri kegiatankegiatan tanpa berkoordinasi dan berkomunikasi terlebih dahulu dengan para pendidik. $^{18}$

\section{Metode Penelitian}

Penelitian ini adalah jenis penelitian lapangan(field research), yaitu penelitian yang pengumpulan datanya dilakukan dan berasal

18 Wawancara dengan Bahrun, pendidik di SMP Al-Kautsar Tanjungpinang, tanggal 4 Pebruari 2017. dari lapangan. Penelitian ini bersifat kualitatif, yaitu penelitian yang menghasilkan menemukan yang tidak dapat dicapai dengan prosedur-prosedur statistik. ${ }^{19}$ Penelitian ini menggunakan metode deskriptif analitis, yaitu metode yang berusaha memaparkan secara sistematis materi-materi pembahasan yang berasal dari berbagai sumber dan kemudian dianalisis untuk memperoleh hasil sebagai kesimpulan. Metode deskriptif ini memusatkan perhatian pada masalah-masalah aktual sebagaimana adanya pada saat penelitian dilakukan. ${ }^{20}$

Sumber data dalam penelitian ini menggunakan teknik wawancara, yaitu teknik pengumpulan data yang dilakukan melalui tatap muka dan tanya jawab langsung antara pengumpul data maupun peneliti terhadap narasumber yang terdiri dari direktur Alkautsar, kepala sekolah, para pendidik dalam waktu selama dua bulan. Metode Pengumpulan Data menggunakan metode observasi, wawancara mendalam, metode analisis data. Penelitian ini menggunakan analisis data kualitatif yaitu upaya yang dilakukan dengan jalan bekerja dengan data. Mengorganisasi data, dan memilihnya menjadi satuan yang dapat dikelola, mensintesiskan, mencari dan menemukan pola, menemukan yang penting dan apa yang dapat diceritakan pada orang lain. ${ }^{21}$ Metode analisis data dalam penelitian ini menggunakan model Milles dan Huberman, yaitu aktifitas dalam data kualitatif yang dilakukan secara interaktif dan berlangsung

\footnotetext{
${ }^{19}$ Basrowi dan Suwandi, Memahami Penelitian Kualitatif, ( Jakarta: Rineka Cipta, 2008), hlm. 1.

${ }^{20}$ Nana Sudjana, Penelitian dan Penelitian Pendidikan, (Bandung: Sinar Baru, 2000), hlm. 64.

${ }^{21}$ Lexy J Moleong, Metodologi Penelitian Kualitatif, (Bandung: PT Remaja Rosdakarya, 2005), hlm. 248.
} 
terus-menerus sampai tuntas, sehingga datanya sudah jenuh. ${ }^{22}$

\section{KAJIAN TEORI (Manajemen Konflik di Lembaga Pendidikan)}

Kata manajemen digunakan hampir di setiap bidang organisasi, mulai dari organisasi pemerintah, swasta, lembaga profit, non profit, bahkan lembaga keagamaan seperti masjid dan gereja. ${ }^{23}$ Menurut George R. Terry sebagaimana dikutip oleh Mulyono, manajemen merupakan sebuah proses yang khas, yang terdiri dari tindakantindakan yang berupa perencanaan, pengorganisasian, penggiatan, dan pengawasan, yang dilakukan untuk menentukan serta mencapai sasaransasaran yang telah ditetapkan melalui pemanfaatan sumber daya manusia dan sumber-sumber lain. ${ }^{24}$

Sedangkan Daniel Webster sebagaimana dikutip Ara Hidayat dan Imam Machali mendefinikan konflik sebagai (1) persaingan atau pertentangan antara pihak-pihak yang tidak cocok satu sama lain, (2) keadaan atau perilaku yang bertentangan, seperti pertentangan pendapat, kepentingan, atau pertentangan antara individu, (3) perselisihan akibat kebutuhan, dorongan, keinginan, atau tuntutan yang bertentangan, dan (4) perseteruan. ${ }^{25}$ Manajemen konflik yang efektif dikatakan berhasil jika mampu mengembangkan

dan

${ }^{22}$ Sugiono, Metode Penelitian Kualitatif..., hlm. 337.

${ }^{23}$ Imam Machali, Ara Hidayat, The Handbook Of Education..., hlm. 2.

${ }^{24}$ Mulyono, Manajemen Administrasi dan Organisasi Pendidikan, (Yokyakarta: Ar-Ruzz Media, 2008), hlm. 16.

${ }^{25}$ Didin Kurniadin dan Imam Machali, Manajemen..., hlm. 264.

mengimplementasikan strategi konflik dengan baik. ${ }^{26}$

\section{a. Pengertian Manajemen Konflik}

1. Pengertian Manajemen

Kata management berasal dari bahasa latin yaitu mano yang berarti tangan, menjadi manus yang berarti bekerja berkali-kali dengan menggunakan tangan, ditambah imbuhan agree yang berarti melakukan sesuatu, sehingga menjadi managiare yang berarti melakukan berkali-kali dengan menggunakan tangan. ${ }^{27}$ Secara tematis kata manajemen berasal dari kata kerja to manage yang berarti mengurus, mengatur, mengemudikan, mengendalikan, menangani, mengelola, menyelenggarakan, menjalankan, melaksanakan, dan memimpin. ${ }^{28}$

Manajemen dalam arti sempit adalah manajemen sekolah atau madrasah yang meliputi perencanaan program sekolah atau madrasah, pelaksanaan program sekolah atau madrasah, kepemimpinan kepala sekolah atau madrasah, pengawas atau evaluasi, dan sistem informasi sekolah atau madrasah. ${ }^{29}$ Sedangkan manajemen dalam arti luas adalah perencanaan, pelaksanaan, dan pengawasan sumber daya organisasi untuk mencapai tujuan secara efektif dan efisien.

\footnotetext{
${ }^{26}$ Fatah Syukur, Manajemen..., hlm. 163.

27 Ara Hidayat dan Imam Machali, Pengelolaan Pendidikan..., hlm. 1.

${ }^{28}$ Imam Machali, Ara Hidayat, The

Handbook..., hlm. 1.

${ }^{29}$ Husaini Usman, Manajemen Teori, Praktik, dan Riset Pendidikan..., hlm. 6.
} 
Mary Parker Follet sebagaimana dikutip oleh Winardi mengemukakan definisi yang amat populer tentang manajemen: management the art of getting things done through other people. ${ }^{30}$

2. Konflik

a. Pengertian Konflik

Berbagai referensi ilmu sosial, banyak yang membahas aspek konflik sebagai materi kajian tentang konflik. ${ }^{31}$ Istilah konflik berasal dari kata kerja bahasa latin conjigere yang berarti saling memukul. Secara etimologis konflik berasal dari bahasa latin con yang berarti bersama dan figere yang berarti benturan atau tabrakan. Dari bahasa latin kemudian diadopsi ke dalam bahasa inggris, conflict yang artinya percekcokan, konflik, perselisihan, dan pertentangan. ${ }^{32}$ Sedangkan ditinjau dari segi akar katanya, kata konflik berasal dari kata configere atau conficium yang mempunyai arti benturan yang menunjuk pada semua jenis bentuk benturan, tabrakan, ketidaksesuaian, pertentangan, perkelahian, oposisi, dan interaksi-interaksi yang bersifat antagonis. ${ }^{33}$ Dalam Kamus Besar

hlm. 2 .

30 Winardi, Manajemen Perilaku Organisasi...,

Konflik..., hlm 16.

32 Hasan Waeduloh, "Manajemen dalam perspektif dakwah", dalam Jurnal Dakwah, Vol.15, Nomor. 1, Juni 2014, hlm. 93.

${ }_{33}$ Sulistyorini dan Fathurrohman

Muhammad, Esensi Manajemen Pendidikan Islam

Pengelolaan Lembaga Untuk Meningkatkan Kualitas

Pendidikan Islam, (Yokyakarta: Teras, 2014), hlm. 296.
Bahasa Indonesia

(Purwodarminto, 1976: 519), sebagaimana dikutip Syarnubi dalam jurnalnya, kata konflik berarti pertentangan atau percekcokan. $^{34}$

Dalam konteks pendidikan, konflik menjadi salah satu kajian menarik dalam ilmu manajemen pendidikan. Kehadiran konflik dalam studi manajemen pendidikan selalu melekat dalam persoalan keseharian yang dialami pengelola lembaga pendidikan.

Pengertian konflik dapat dilihat dari beberapa sudut pandang, yaitu:

a) Pandangan tradisional.

Dari segi pandangan tradisional menyatakan bahwa semua jenis konflik itu buruk. Konflik di nilai suatu yang negatif, merugikan, dan harus dihindari.

b) Pandangan hubungan manusia

Pandangan hubungan manusia menyatakan bahwa konflik merupakan peristiwa yang wajar terjadi di semua organisasi. Konflik ini tidak dapat dikatakan baik atau tidak baik, namun merupakan hal yang normal dalam sebuah organisasi.

c) Pandangan interaksionis

Pandangan interaksionis ini menyatakan bahwa konflik adalah hal yang baik dan perlu

\footnotetext{
34 Syarnubi, "Manajemen Konflik dalam Pendidikan Islam dan Problematikanya", dalam Jurnal Tadrib, Vol 2, Nomor. 1, Juni 2016, hlm. 2.
} 
dipertahankan, bahkan cenderung mendorong terjadinya konflik, karena berasumsi bahwa bahwa kelompok atau organisasi yang kooperatif, tenang, damai, serasi cenderung menjadi statis, apatis, tidak aspiratif dan tidak inovatif. Menurut aliran pemikiran ini, konflik perlu dipertahankan pada tingkat minimum secara berkelanjutan, sehingga tetap bersemangat, kritis diri dan kreatif. 35

d) Tahapan konflik

Konflik terjadi karena ada lima tahapan yang merupakan proses secara berurutan, yaitu: konflik tersembunyi (laten konflict), konflik terasakan (preceived conflict), konflik diwujudkan (felt conflict), konflik teraba (manifest conflict), dan akibat konflik (conflict aftermath).

Menurut Muzamil Qomar, tugas dari seorang manajer atau pimpinan di Lembaga Pendidikan Islam adalah menyelesaikan konflik pada tahap pertama yaitu pada tahap laten atau potensial yang masih berupa perbedaan, baik individu maupun kelompok. Penyelesaian yang dilakukan pada tahap ini merupakan langkah cepat tanggap yang berpengaruh secara signifikan dalam

35 Saefullah, Manajemen Pendidikan Islam, (Bandung: Pustaka Setia, 2012), hlm. 295-296. menekan terjadinya konflik yang sesungguhnya. ${ }^{36}$

b. Penyebab konflik

Edi Santosa dan Lilin

Budiati menyebutkan beberapa alasan yang menjadikan faktor penyebab konflik sebagai berikut:

c. Perbedaan individu

Perbedaan individu ini meliputi perbedaan pendirian dan perasaan. Setiap manusia adalah individu yang unik. Artinya, setiap orang memiliki pendirian dan perasaan yang berbeda-beda satu dengan yang lainnya. Perbedaan yang nyata ini dapat menjadi faktor penyebab konflik sosial.

a) Perbedaan latar belakang kebudayaan

Perbedaan ini membentuk pribadi-pribadi yang berbeda. Seseorang sedikit banyak akan terpengaruh dengan pola pemikiran dan pendirian kelompoknya. Pemikiran dan pendirian itu pada akhirnya akan menghasilkan perbedaan individu yang dapat memicu konflik.

b) Kurangnya komunikasi

Kita tidak dapat meremehkan komunikasi antarmanusia karena konflik bisa terjadi hanya karena dua pihak kurang komunikasi. Kegagalan berkomunikasi terjadi karena dua pihak tidak dapat menyampaikan pikiran, perasaan, dan tindakan sehingga membuka jurang 
perbedaan informasi, bahkan ideologi atas apa yang diperebutkan.

c) Perbedaan kepentingan antara individu atau kelompok

Manusia memiliki perasaan, pendirian, ataupun latar belakang kebudayaan yang berbeda. Oleh sebab itu, dalam waktu yang bersamaan, masing-masing orang atau kelompok memiliki kepentingan yang berbeda-beda. Kadang-kadang orang dapat melakukan hal yang sama dengan tujuan yang berbeda-beda. ${ }^{37}$

d) Sumber konflik

Menurut Wirawan, ada beberapa faktor yang menyebabkan sumber konflik , yaitu:

a) Keterbatasan sumber

Keterbatasan sumber dapat menimbulkan terjadinya kompetisi di antara manusia untuk mendapatkan sumber yang diperlukannya dan hal ini sering menimbulkan konflik. Dalam sebuah organisasi, sumbersumber yang dimaksud bisa berupa anggaran, fasilitas kerja, jabatan, kesempatan untuk berkarier, dan sebagainnya. Dalam masyarakat konflik karena keterbatasan sumber penghidupan sering terjadi. Contohnya konflik antara para preman dan pengangguran yang memperebutkan lahan parkir dan lain-lain.

${ }^{37}$ Edi Santosa dan Lilin Budiati, Manajemen Konflik..., hlm. 431. b) Tujuan yang berbeda

Konflik dapat terjadi karena pihak-pihak yang terlibat konflik mempunyai tujuan yang berbeda. Sebagai contoh adalah pengusaha industri yang bertujuan memproduksi barang atau memberikan jasa pelayanan serendah mungkin dengan menekan upah buruh serendah mungkin. Namun para buruh menginginkan bekerja seminimal mungkin dengan upah dan jaminan sosial sebaik mungkin.

c) Saling tergantung

Konflik terjadi karena pihak-pihak yang terlibat konflik memiliki tugas yang tergantung satu sama lain. Konflik terjadi di antara pihak yang saling membutuhkan, saling berhubungan dan tidak bisa meninggalkan satu sama lain tanpa konsekuensi negatif.

d) Diferensiasi organisasi atau struktur organisasi juga dapat menjadi sumber konflik karena perbedaan pola pikir, perilaku, dan perbedaan pendapat mengenai sesuatu.

e) Sistem imbalan yang tidak layak

Konflik antara karyawan dan manajemen perusahaan sering terjadi. Hal ini biasanya disebabkan oleh imbalan yang dianggap tidak adil dan layak oleh karyawan. 
f) Komunikasi yang tidak baik

Komunikasi yang tidak baik sering kali menimbulkan konflik dalam organisasi. Perilaku yang berbeda, gaya berbicara atau budaya komunikasi kelompok masyarakat tertentu sering kali menyinggung perasaan orang yang tidak memahaminya.

g) Pribadi orang

Kepribadian seperti sombong, selalu curiga, egois, merasa paling benar, ingin menang sendiri, kurang dapat mengendalikan emosinya, adalah sifat-sifat yang mudah menyulut konflik jika berinteraksi dengan orang lain. ${ }^{38}$

h) Jenis-jenis konflik

Terdapat berbagai macam jenis konflik dan dapat dikelompokkan berdasarkan berbagai kriteria dan sudut pandang diantaranya sebagai berikut:

a) Konflik dilihat dari fungsi.

Berdasarkan fungsinya, Robbins sebagaimana dikutip oleh Kurniadin dan Machali membagi konflik menjadi dua macam, yakni konflik fungsional (functional conflict) dan konflik disfungsional (dysfunctional conflict).

i. Konflik fungsional

Konflik yang mendukung pencapaian tujuan kelompok dan memperbaiki kinerja kelompok. Konflik ini menilai pertentangan antar kelompok yang mempertinggi atau

38 Wirawan, Konflik ..., hlm. 12. menguntungkan prestasi organisasi.

ii. Konflik disfungsional

Konflik yang merintangi, dalam artian konflik yang merintangi pencapaian tujuan kelompok. Setiap pertentangan atau interaksi antara kelompok yang mengganggu organisasi atau merintangi upaya pencapaian tujuan organisasi.

iii. Konflik dilihat dari pihak yang terlibat di dalamnya

Berdasarkan pihak-pihak yang terlibat di dalam konflik, konflik dapat dibagi menjadi enam macam, yaitu:

Konflik dalam diri individu (conflict within the individual). Konflik ini terjadi jika seseorang harus memilih tujuan yang saling bertentangan atau karena tuntunan tugas yang melebihi batas kemampuannya.

i. Konflik antara individu dalam organisasi yang sama (conflict among individuals), dimana hal ini sering diakibatkan oleh perbedaan-perbedaan

kepribadian. Konflik ini juga berasal dari adanya konflik antar peranan( seperti antara manajer dan bawahan).

ii. Konflik antar individu dan kelompok (conflict among individuals and groups), yang berhubungan dengan cara individu menanggapi tekanan untuk keseragaman yang dipaksakan oleh kelompok kerja mereka. Sebagai contoh seorang individu mungkin dihukum atau diasingkan oleh kelompok kerjanya karena melanggar norma-norma kelompok. 
iii. Konflik antar kelompok dalam organisasi yang sama (conflict among groups in the same organization), karena terjadi pertentangan antar kelompok.

iv. Konflik antar organisasi (conflict among organizations), yang timbul sebagai akibat bentuk persaingan ekonomi dan sistem perekonomian suatu negara. Konflik ini telah mengarahkan timbulnya pengembangan produk baru, teknologi, dan jasa, harga-harga lebih rendah, dan penggunaan sumber daya lebih efisien.

v. Konflik antar individu dalam organisasi yang berbeda (conflict among individuals in different organizations), konflik ini terjadi sebagai akibat sikap atau perilaku dari anggota suatu organisasi dan berdampak negatif bagi anggota organisasi yang lain. Misalnya, seorang manajer public relations yang menyatakan keberatan atas pemberitaan yang dilansir seorang jurnalis. ${ }^{39}$

\section{E. Konsep dan Teori-Teori Manajemen Konflik}

Manajemen konflik termasuk suatu pendekatan yang berorientasi pada proses yang mengarahkan bentuk komunikasi dari pelaku ataupun pihak luar dan bagaimana mempengaruhi kepentingan dan interpretasi. ${ }^{40}$ Wirawan mendefinisikan manajemen konflik

${ }^{39}$ Yani Tri Wijayanti, Asep Suryana, dkk, "Manajemen Konflik Organisasi dalam Perspektif Islam", dalam Jurnal Komunikasi Profetik, Vol 8, Nomor. 1, April 2015, hlm. 45.

40 Agus Santosa dan Lilin Budiati, Manajemen..., hlm. 118-119. sebagai proses pihak yang terlibat konflik atau pihak ketiga menyusun strategi konflik dan menerapkannya untuk mengendalikan konflik agar menghasilkan resolusi yang diinginkan. ${ }^{41}$

Manajemen konflik sebagai proses pihak yang terlibat konflik atau pihak ketiga yang menyusun strategi konflik dan menerapkannya untuk mengendalikan konflik agar menghasilkan resolusi sesuai yang diinginkan. ${ }^{42}$ Kepala sekolah sebagai pimpinan tertinggi di sekolah harus mampu mengelola konflik dengan baik sehingga memberikan manfaat positif dan terhindar dari akibat yang negatif. ${ }^{43}$

Manurut Wirawan, ada beberapa teori mengenai gaya manajemen konflik yang dikembangkan oleh para ahli ${ }^{44}$, di antaranya adalah teori Girld, teori Thomas dan Kilman, dan teori Rahim. ${ }^{45}$

\section{F. Teori Penyelesaian Sengketa}

H.L.A. Hart sebagaimana dikutip oleh Eman Suparman dalam teorinya berkenaan dengan penegakan hukum dan penyelesaian sengketa, yang didasarkan pada perbedaan masyarakat secara dikotomi melalui struktur kehidupan normatifnya. ${ }^{46}$ Kedua tatanan normatif masyarakat tersebut adalah primary rules of obligation dan secondary rules of obligation. Masyarakat yang berada pada peringkat primary rules of obligation, ditandai dengan kondisi seperti berikut: pertama komunitas

\footnotetext{
41 Wirawan, Manajemen..., hlm. 129.

${ }^{42}$ Wirawan, Konflik..., hlm. 129

${ }^{43}$ E. Mulyasa, Menjadi..., hlm. 246.

${ }^{44}$ Wirawan, Konflik..., hlm. 138-144.

${ }^{45}$ Lihat pada Wirawan, Konflik Dan Manajemen

Konflik: Teori, Aplikasi, dan Penelitian, Jakarta: Salemba Humanika, 2013.

${ }^{46}$ Eman Suparman, Arbitrase dan Dilema Penegakan Keadilan, (Jakarta: PT Fikahati Kristiandi, 2012), hlm. 35.
} 
kecil, kedua: didasarkan ikatan kekerabatan, ketiga: memiliki kepercayaan dan sentimen umum, dan keempat berada di tengah-tengah lingkungan yang stabil. ${ }^{47}$

\section{G. Teori- Teori Perilaku Organisasi/Gaya Kepemimpinan}

Tipe kepemimpinan merupakan suatu pola perilaku yang khas pada saat mempengaruhi anak buahnya, apa yang dipilih oleh pemimpin untuk dikerjakan, cara pemimpin bertindak dalam mempengaruhi anggota kelompok membentuk gaya kepemimpinan. ${ }^{48}$

Stephen P.Robbins dan Mary Coulter memfokuskan pada kualitas individu dan karakter atau sifat. ${ }^{49}$ Robbins membagi teori perilaku kepemimpinan dalam tiga bentuk, yaitu pertama: tipe otokratis (autocratic style), tipe demokratis (democratic style), tipe laissez-faire (laissezfaire style). Sedangkan Sondang P. Siagian menyatakan bahwa ada lima gaya kepemimpinan yang diakui keberadaannya. ${ }^{50}$ Adapun Imam Machali dan Ara Hidayat membagi dalam delapan bagian mengenai tipe dan gaya kepemimpinan. ${ }^{51}$

${ }^{47}$ Lihat pada Eman Suparman, Arbitrase dan Dilema Penegakan Keadilan, Jakarta: PT Fikahati Kristiandi, 2012.

${ }^{48}$ Leny Marlina, "Tipe-Tipe Kepemimpinan dalam Manajemen Pendidikan”, dalam Jurnal Ta'dib, Fakultas Tarbiyah dan Keguruan, Vol. 18, Nomor 2, November 2013, hlm. 224.

${ }^{49}$ Stephen P.Robbin, Mary Coulter, Management Skill and Aplication, (England: Pearson Education, 2013), hlm. 490.

${ }^{50}$ Lihat dalam Sondang P. Siagian, Teori dan

Praktek Kepemimpinan, cet. ke-6, Jakarta: PT Rineka Cipta, 2010.

${ }^{51}$ Lihat dalam Imam Machali, Ara Hidayat, The Handbook of Education Management, cet. ke-1, Jakarta: Kencana, 2016.

\section{H. HASIL PENELITIAN (Konflik di SMP Al-Kautsar)}

Konflik di SMP Al-Kautsar bisa dilihat dari kurang baiknya hubungan antara atasan dan bawahan, kurang kompaknya antara kepala sekolah dan para pendidik dalam berbagai kegiatan yang berkaitan dengan pembelajaran. Sekalipun beberapa konflik yang terjadi bermanfaat bagi kemajuan organisasi, akan tetapi yang sering terjadi dan muncul ke permukaan adalah konflik yang disfungsional. ${ }^{52}$ Sebagaimana dijelaskan oleh Robbins dalam Kurniadin ${ }^{53}$, bahwa konflik disfungsional merupakan konflik yang merintangi setiap tujuan dari setiap organisasi. Setiap konflik yang terjadi antar individu maupun kelompok dapat dikategorikan menghambat dan mengganggu pencapaian organisasi. Konflik ini hanya memuaskan individu dan menurunkan kinerja organisasi. Soetopo juga menyatakan bahwa konflik harus dihindari dan dihilangkan dari sebuah organisasi karena hanya akan mengganggu organisasi dan menghambat prestasi. $^{54}$

Di SMP Al-Kautsar, dalam kedudukan struktural organisasi antara atasan dan bawahan juga memicu konflik. ${ }^{55} \mathrm{Hal}$ ini bisa dilihat ketika kepala

52 Indriyo Gitosudarmo, I Nyoman Sudita, Perilaku Keorganisasian, (Yokyakarta: BPFE, 2014), hlm. 98.

53 Didin Kurniadin, Imam Machali, Manajemen..., hlm. 143.

${ }^{54}$ Hendyat Soetopo, Perilaku..., hlm. 259.

55 Kepala sekolah sebagai manajer pendidikan merasa dengan posisi yang dimiliki bisa mengatur dan sering menyuruh pada bawahannya sesuai apa yang diinginkan. Sedangkan beberapa pendidik senior marasa lebih berpengalaman karena telah mempunyai jam mengajar yang sudah lama dan sering mengikuti berbagai pelatihan yang diadakan oleh kemendiknas. Hal ini yang membuat sulit untuk saling berkoordinasi antara kepala sekolah dan para pendidik di SMP AlKautsar. 
sekolah SMP Al-Kautsar tidak dilibatkan pada saat mengadakan peringatan hari besar keagamaan, yang seharusnya kepala sekolah sebagai manajer harus dilibatkan. Begitu pula dengan kepala sekolah, terkadang ada kegiatan perlombaan yang membutuhkan pendidik pendamping, namun kepala sekolah bertindak sendiri dan terkadang hanya melibatkan pendidik yang disenangi. ${ }^{56}$ Sebagai manusia yang unik, para pelaku pendidikan pasti mempunyai cara pandang yang berbedabeda dan tujuan yang tidak sama dalam usaha meningkatkan kualitas pendidikan, yang terkadang juga menimbulkan konflik. Hal ini berkorelasi dengan pernyataan Budiati dan Santosa bahwa konflik bisa bersumber dari perbedaan individu dan kelompok, bahkan terkadang setiap individu mempunyai kepentingan yang berbeda. ${ }^{57}$

Wirawan juga menyatakan bahwa konflik dapat disebabkan oleh cara pandang dan tujuan berbeda-beda dari pelaku organisasi. ${ }^{58}$ Misalnya manajer pendidikan menginginkan bawahannya bekerja semaksimal mungkin dengan memberikan gaji serendah mungkin, tapi bawahannya menginginkan bekerja seminimal mungkin dengan gaji yang

56 Baik kepala sekolah dan para pendidik terkadang berjalan sendiri-sendiri dalam berbagai kegiatan seperti lomba yang diadakan dalam menyambut hari-hari besar Islam maupun kegiatankegiatan lainnya. Terkadang para pendidik mengadakan kegiatan lomba dengan peserta didik, namun tidak melibatkan kepala sekolah. Begitupun ketika kepala sekolah ketika mengadakan kegiatan perlombaan di sekolah, hanya memilih beberapa pendidik yang dia senangi tanpa melibatkan seluruh pendidik. Hal ini menunjukkan kurang kompak dan solidnya hubungan antara kepala sekolah dan para pendidik.

${ }^{57}$ Lilin Budiati dan Budi Santosa, Manajemen Konflik..., hlm. 432.

58 Wirawan, Konflik..., hlm. 12 tinggi. Hal ini juga berlaku di SMP $\mathrm{Al}-$ Kautsar Tanjungpinang yang mana manajer pendidikan menuntut para pendidik untuk bekerja dengan maksimal, terutama pendidik yang tinggal di asrama. ${ }^{59}$.

Ada beberapa kebijakan dari kepala sekolah yang menimbulkan konflik dengan para pendidik di SMP Al-Kautsar. Salah satu contoh adalah kebijakan kepala sekolah SMP Al-Kautsar yang sering melakukannya tanpa koordinasi dengan para pendidik. ${ }^{60}$

Bahrun, salah satu pendidik di SMP Al-Kautsar ketika wawancara dengan peneliti mengatakan:

"iya ini yang menarik, untuk konflik yang sering terjadi di SMP Al-Kautsar terkait dengan kebijakan kepala sekolah pada para pendidik, biasanya apapun yang terjadi langsung dilakukan tanpa koordinasi dengan para guru terlebih dulu, kepala sekolah langsung mengambil

59 Di SMP Al-Kautsar ada pendidik yang setiap hari berangkat dari rumah dan ada sebagian pendidik yang berangkat dan tinggal di asrama. Bagi pendidik yang tinggal di asrama, para pendidik ini mempunyai tugas tambahan yang mana selain mengajar di SMP Al-kautsar, mereka juga harus mengajar di asrama seperti mengajar membaca alqur'an, mengajar mufrodat setiap pagi, serta mengawasi peserta didik yang tinggal di asrama selama sehari penuh. Para pendidik mengeluhkan tugas yang berat tidak sebanding dengan gaji yang mereka terima. Namun para pendidik yang tinggal di asrama tidak bisa berbuat banyak dengan keadaan seperti itu. Para pendidik pernah mengusulkan kepada direktur AlKautsar agar ada tambahan gaji karena tugas mereka yang lebih berat dari pada para pendidik yang tidak tinggal di asrama. Namun sampai saat ini belum ada realisasi dari pihak direktur. Para pendidik yang tinggal di asrama tetap berharap ada perbaikan gaji, karena di samping tugas yang berat juga biaya hidup di Kota Tanjungpinang yang mahal.

${ }^{60}$ Wawancara dengan Bahrun, pendidik di SMP Al-Kautsar, tanggal 15 Pebruari 2018. 
kebijakan langsung, dalam artian apapun tugas yang seharusnya di lakukan oleh para guru, malah dilakukan oleh kepala sekolah. Tugas bawahan seperti membuat panitia ujian atau semester malah dilakukan kepala sekolah sendiri yang itu bukan tugasnya, entah kurang percaya atau apa, yang seharusnya dilakukan oleh para guru. Intinya kepala sekolah harus memberi koordinasi langsung dengan para guru apapun yang terkait kebijakan yang dikeluarkan."

Berdasarkan hasil wawancara di atas, didapat informasi bahwa kepala sekolah di SMP Al-Kautsar melakukan tugas yang harusnya dilakukan oleh pendidik dan tidak melakukan koordinasi terlebih dahulu dalam mengambil beberapa kebijakan. Hal ini sering dilakukan oleh kepala sekolah di SMP AlKautsar yang disebabkan kurang percayanya pada pendidik dengan alasan akan tidak optimal. ${ }^{62}$

Hal senada juga disampaikan oleh Ridwan, salah satu pendidik SMP AlKautsar ketika wawancara dengan peneliti mengatakan:

"kebijakan kepala sekolah memberikan tugas ke guru, mau menjalankan tapi kadang-kadang

${ }^{61}$ Wawancara dengan Bahrun, pendidik di SMP Al-Kautsar, tanggal 11 Pebruari 2018.

62 Kepala sekolah sering mengambil alih tugas-tugas yang seharusnya dilakukan oleh para pendidik. Seperti membuat panitia ujian, panitia kegiatan lomba-lomba pada hari besar, kegiatankegiatan di sekolah yang seharusnya dirapatkan dulu, namun kepala sekolah sudah mempunyai nama-nama yang dimasukkan dalam panitia. Hal ini bisa memicu perasaan cemburu di antara pendidik terutama yang tidak dilibatkan dalam kepengurusan. Sedangkan para pendidik menginginkan agar kepala sekolah memberikan kesempatan dan kepercayaan untuk melakukan tugas-tugas yang sesuai dengan tupoksinya. sudah dijalankan dulu oleh kepala sekolah, kasih kepercayaan dulu kasih tenggang waktu jadi kayak belum ada kepercayaan pada guru-guru kurang, seharusnya kepala sekolah memberi tugas ke guru minimal kasih kepercayaan dan kasih tenggang waktu." ${ }^{63}$

Berdasarkan hasil wawancara di atas didapat informasi bahwa kepala sekolah kurang menaruh kepercayaan kepada para pendidik.

Sebagaimana dalam teori perilaku kepemimpinan yang dijelaskan oleh Robbins ${ }^{64}$, Siagian ${ }^{65}$, dan Machali ${ }^{66}$ menyatakan bahwa pemimpin dengan tipe otokratik berperan sebagai pemain tunggal, setiap perintah dan kebijakan ditetapkan tanpa berkonsultasi dengan bawahannya. Dalam hal ini Anak buah tidak pernah diberi informasi mendetail mengenai rencana dan tindakan yang harus dilakukan. Seorang pemimpin yang otoriter akan menunjukkan berbagai sikap yang menonjolkan ke-akuan-nya. Pemimpin dengan tipe otokratik ini membuat keputusan yang hanya mempengaruhi satu pihak.

Masih terkait dengan kebijakan kepala sekolah, Ramanda, salah satu pendidik di SMP Al-Kautsar ketika wawancara dengan penulis mengatakan:

"yaaa ini sering terjadi karena kebijakan yang dilakukan oleh kepala sekolah tidak disosialisasikan terlebih dulu kepada bawahannya. Ini yang

\footnotetext{
${ }^{63}$ Wawancara dengan Ridwan, pendidik di SMP Al-Kautsar, tanggal 28 Pebruari 2018

${ }^{64}$ Stephen P.Robbin, Mary Coulter, Management..., hlm. 490

65 Sondang P. Siagian, Teori..., hlm. 31.

66 Imam Machali, Ara Hidayat, The

Handbook..., hlm. 90.
} 
menurut saya bisa menimbulkan konflik dan kejadian ini sebenarnya tidak perlu terjadi apabila ada sosialisasi dan komunikasi yang intens antara kepala sekolah dengan para pendidik. Makanya komunikasi itu penting dan salah satu alat yang utama untuk kepala sekolah dan para guru". ${ }^{67}$

Berdasarkan hasil wawancara di atas didapat informasi bahwa kurangnya sosialisasi dan komunikasi antara kepala sekolah dan pendidik. Komunikasi antara kepala sekolah dan para pendidik di SMP Al-Kautsar masih sangat minim, hal ini lebih disebabkan masih adanya perasaan ego di antara mereka. Komunikasi akan berjalan dengan baik apabila ada saling pengertian, saling bisa melihat kekurangan pada dirinya sendiri, dan tidak merasa paling benar dan berpengalaman.

Sebagaimana dijelaskan pada bab sebelumnya, Wirawan menyatakan bahwa penyebab konflik di antaranya adalah kurangnya komunikasi antara pelaku organisasi. Komunikasi yang tidak baik sering menimbulkan konflik dalam organisasi. Perilaku antara atasan dan bawahan yang berbeda, gaya berbicara atau budaya komunikasi dalam organisasi sering kali menyinggung perasaan orang yang tidak memahaminya. ${ }^{68}$

Dalam ranah pendidikan, komunikasi merupakan unsur yang sangat penting kedudukannya. Bahkan sangat besar peranannya dalam menentukan keberhasilan, sering ada argumen yang

${ }^{67}$ Wawancara dengan Ramandha, Pendidik di SMP Al-Kautsar, tanggal 14 Pebruari 2018.

${ }^{68}$ Wirawan, Konflik ..., hlm. 12. menyatakan bahwa tinggi rendahnya suatu capaian mutu pendidikan dipengaruhi oleh faktor komunikasi. ${ }^{69}$ Tanpa komunikasi organisasi tidak akan berjalan. ${ }^{70}$ Komunikasi yang terjalin dengan baik dalam sebuah lembaga pendidikan, akan menciptakan iklim keterbukaan, membangun atmosfir kebersamaan, meningkatkan rasa memiliki pada sebuah lembaga, memberikan informasi yang jelas untuk mengatasi desas desus dan gosip yang beredar di dalam lembaga pendidikan yang bisa mengganggu kinerja. ${ }^{71}$

\section{Manajemen Konflik dalam}

\section{Kepemimpinan Kepala Sekolah di SMP Al-Kautsar}

Kepala sekolah adalah pemimpin komunitas sekolah yang paling bertanggung jawab mewujudkan cita-cita bersama. ${ }^{72}$ Dalam petuahnya yang terkenal, bapak pendidikan $\mathrm{Ki}$ Hajar Dewantoro mengatakan ing ngarso sung tulodho, ing madyo mangun karso, tut wuri bandayani, yang memiliki arti di belakang memberi dorongan atau semangat, di tengah-tengah membangun kehendak atau kemauan, berinisiatif, dan di depan dapat memberi contoh atau teladan yang baik, baik dalam pengetahuan, sikap, maupun dalam perbuatan. ${ }^{73}$

${ }^{69}$ Pawit M.Yusup, Komunikasi Pendidikan dan Komunikasi Instruksional, (Bandung: PT Remaja Rosdakarya, 1990), hlm. 13.

${ }^{70}$ Abdul Aziz Wahab, Anatomi Organisasi dan Kepemimpinan Pendidikan, (Bandung: CV Alfabeta, 2011), hlm.144.

${ }^{71}$ Yosal Irianto, Usep Syaripudin, Komunikasi

Pendidikan, (Bandung: Simbiosa Rekatama

Media, 2013), hlm. 102.

72 Budi Suhardiman, Studi Pengembangan Kepala Sekolah, Konsep dan Aplikasinya, ( Jakarta: PT Rineka Cipta, 2012), hlm. 3.

${ }^{73}$ Pawit M.Yusup, Komunikasi Pendidikan..., hlm. 12 
Berkaitan manajemen konflik kepemimpinan di SMP Al-Kautsar, direktur SMP Al-Kautsar M.Supeno ketika wawancara dengan peneliti mengatakan:

“eee begini, jadi yang bagus itu kepala sekolah harus lebih komunikatif lagi dan itu penting, juga kalau nyuruh bahasanya yang baik misalnya menyuruh tapi dengan bahasa mengajak, pelan-pelan biar guru-guru gak tersinggung yang kita ajak bicara kan beda-beda karakternya, sebenarnya kalau guru-guru diperhatikan sering diajak ngobrol diajak tukar pendapat dia malah senang." 74

Berdasarkan hasil wawancara di atas, didapatkan informasi bahwa komunikasi/kompromi menjadi hal yang penting dan urgen antara kepala sekolah dengan para pendidik. Komunikasi antara kepala sekolah dan para pendidik di SMP Al-Kautsar harus ditingkatkan. Hal ini sangat penting agar antara kepala sekolah dan para pendidik di SMP Al-Kautsar bisa saling bertukar ide, gagasan, dan memecahkan permasalahan bersamasama.

Pernyataan yang hampir sama disampaikan oleh Puji Lestari, salah satu pendidik senior di SMP Al-Kautsar ketika wawancara dengan peneliti mengatakan:

"sering ada perbedaan pendapat tentang pembagian tugas terkadang tidak sesuai dengan guru yang bersangkutan. musyawarah kepala sekolah dengan guru-guru sebelum rapat itu penting dan wajib untuk mengetahui masalah yang akan dibahas dirapat, kurangnya

${ }^{74}$ Wawancara dengan M. Supeno, Direktur SMP Al-Kautsar, tanggal 11 Pebruari 2018. komunikasi menjadi kendala utama menurut saya pribadi. Sebenarnya sangat simple sekali untuk meminimalisir konflik. Kepala sekolah harus lebih komunikasi lagi dengan guru-guru." 75

Berdasarkan hasil wawancara di atas, didapatkan informasi bahwa musyawarah dan komunikasi menjadi hal penting bagi kepala sekolah dan para pendidik untuk menyamakan persepsi dan mengetahui permasalahan yang akan dibawa ke rapat yayasan. ${ }^{76}$ Di samping itu, komunikasi/kompromi adalah cara untuk meminimalisir konflik antara kepala sekolah dan bawahannya. Sebagaimana dijelaskan dalam teori manejemen konflik, Gird $^{77}$, Kilman ${ }^{78}$, dan Rahim ${ }^{79}$ menyatakan bahwa perhatian seorang manajer yang sedang (tidak tinggi atau tidak rendah) terhadap produksi dan bawahannya cenderung bernegosiasi/berkompromi jika

${ }^{75}$ Wawancara dengan Puji Lestari, Pendidik di SMP Al-Kautsar, tanggal 10 Pebruari 2018.

76 Kepala sekolah dan para pendidik biasannya membuat ringkasan sendiri yang akan dibawa ke rapat mingguan dan akan membacakan ringkasan yang berupa temuan-temuan berkaitan dengan lembaga pendidikan. Setelah direktur membuka rapat mingguan dan menyampaikan beberapa yang dianggap penting, kepala sekolah dan para pendidik diberi kesempatan untuk menyampaikan temuan-temuan dan masukan secara bergantian. Sebagian pendidik berharap sebelum rapat berkomunikasi dulu tentang apa yang mau dibahas di rapat sehingga tahu permasalahan yang ada. Namun kepala sekolah tidak bermusyawarah dan berkomunikasi terlebih dahulu dengan para pendidik. Sehingga para pendidik terkadang tidak tahu dan kaget dengan apa yang disampaikan oleh kepala sekolah di rapat. Hal ini terkadang memicu konflik antara kepala sekolah dan para pendidik, karena apa yang disampaiakan kepala sekolah terkadang juga langsung mengkritisi kinerja para pendidik. Para pendidik menginginkan agar sebelum kepala sekolah membahas temuannya selama seminggu di rapat, dikonfirmasikan dulu pada pendidik agar bisa saling menyamakan tujuan.

77 Wirawan, Konflik..., hlm. 138.

78 Ibid..., hlm, 141.

${ }^{79}$ Ibid..., hlm, 144. 
mengelola konflik. Dengan menggunakan strategi give and take, kedua belah pihak yang terlibat konflik mencari alternatif titik tengah yang memuaskan sebagian keinginan mereka. Dalam keadaan tertentu, kompromi dapat berarti membagi perbedaan di antara dua posisi dan memberikan konsensi untuk mencari titik tengah. Kompromi juga berada di persimpangan dari kedua belah pihak dan berusaha mencapai memenuhi tujuan dari kedua belah pihak tanpa berusaha memaksimalkannya. Sehingga dapat dijelaskan bahwa antara teori dan penuturan beberapa pendidik di SMP AlKautsar sudah cukup sesuai.

Dalam penyelesaian konflik di SMP Al-Kautsar, direktur SMP Al-Kautsar Supeno ketika wawancara dengan peneliti mengatakan:

"inikan di wilayah internal sendiri, biasanya kalau ada masalah yang berkaitan dengan sekolahan kita komunikasikan terlebih dahulu, kita selesaikan di rapat kita musyawarahkan bersama kita cari solusinya, kalau ada konflik tetap kita bawa ke rapat meskipun kadang juga kita panggil dulu yang bersangkutan kita tanya masalahnya apa yang jelas setiap ada permasalahan penyelesaiannya dengan musyawarah lewat rapat mingguan, makanya lembaga ini mengedepankan musyawarah karena itu penting sekali". 80

Berdasarkan hasil wawancara di atas, didapat informasi bahwa musyawarah, kompromi/negosiasi dan

${ }^{80}$ Wawancara dengan M. Supeno, direktur di SMP Al-Kautsar, tanggal 11 Pebruari 2018. komunikasi sebagai resolusi atau manajemen konflik kepemimpinan di SMP Al-Kautsar Tanjungpinang. Musyawarah sangat penting sekali dalam menyelesaikan setiap masalah yang terjadi di SMP AlKautsar. Musyawarah atau rapat mingguan yang rutin diadakan di rumah direktur AlKautsar dilakukan untuk membahas semua permasalahan, baik yang positif maupun negatif. ${ }^{81}$ Musyawarah, komunikasi, negosiasi/kompromi diperlukan dalam setiap bentuk penyelesaian konflik sehingga semuanya akan mendapat solusi yang seimbang. Pendekatan ini lebih tepat disebut pendekatan dengan mencari jalan tengah atau jalan damai. Jalan tengah yang diambil tentunya akan memperkecil perbedaan atau kesenjangan pendapat sehingga konflik yang dihadapi merupakan tugas dan beban bersama. Pendekatan ini sangat baik bagi hubungan sosial dalam bekerja sehingga mereka tidak merasa diremehkan atau mendapat tempat yang sama. Sebagaimana telah dijelaskan oleh Kurniadin bahwa menyelesaikan konflik melalui jalan tengah yang bisa diterima oleh pihak-pihak yang bersangkutan. Dalam artian manajer mencoba menyelesaikan konflik melalui jalan tengah

81 Setiap malam senin yang mana direktur, kepala sekolah dan para pendidik berkumpul di rumah direktur Al-Kautsar untuk melakukan kegiatan rutin musyawarah atau rapat mingguan. Rapat ini dibuka oleh direktur dan menyampaikan point-point penting yang akan dibahas dalam rapat. Rapat mingguan ini biasannya di mulai pada pukul tujuh malam sampai jam sepuluh malam. Rapat mingguan bertujuan agar permasalahan yang terjadi di sekolah maupun di asrama bisa dicarikan jalan keluarnya dalam kurun waktu seminggu. Biasanya setiap pendidik disuruh menyampaikan temuannya, kemudian direktur memberikan masukan dan penyelesaian berkaitan dengan masalah tersebut. Namun tidak semua temuan yang disampaikan para pendidik bisa dicarikan jalan keluar atau solusi. 
yang dapat diterima oleh pihak yang bertikai.

Dalam hal ini direktur SMP AlKautsar biasanya memanggil pihak-pihak yang berkonflik dan membantu menyelesaikan konflik dengan mengambil jalan tengah. ${ }^{82} \mathrm{Hal}$ ini juga berkorelasi dengan pernyataan Rifai bahwa dengan kompromi, manajer mencoba menyelesaikan konflik melalui jalan tengah yang bisa diterima oleh pihak-pihak yang bersangkutan. Dalam artian manajer mencoba menyelesaikan konflik melalui jalan tengah yang dapat diterima oleh pihak yang bertikai. ${ }^{83}$

Dalam menyelesaikan berbagai permasalahan, termasuk konflik, di SMP Al-Kautsar biasanya dibahas pada rapat antara direktur, kepala sekolah dan para pendidik yang dilakukan seminggu sekali pada hari Minggu dengan mengedepankan kekerabatan dan kekeluargaan. ${ }^{84} \mathrm{Hal}$ ini

82 Setiap ada permasalahan atau konflik di SMP Al-Kautsar yang terjadi pada pendidik, biasanya ditangani langsung oleh direktur Al-Kautsar dengan cara memanggil terlebih dahulu menghadap ke rumah direktur. Kemudian direktur menanyakan permasalahan yang sedang dihadapi dan memberikan alternatif atau solusi agar permasalahan dapat diselesaikan dengan jalan kekeluargaan. Kompromi atau jalan tengah biasa dilakukan direktur Al-Kautsar dalam menyelesaikan konflik karena menganggap bahwa mereka masih dalam satu keluarga, sehingga dapat diselesaikan dengan mudah dan tidak ada pihak yang dirugikan. Dalam rapat mingguan direktur kembali menyampaikan permasalahan yang terjadi pada para pendidik sehingga anggota rapat bisa melihat dan mendengarkan dengan seksama.

${ }^{83}$ Didin Kurniadin, Manajemen ..., hlm. 272.

84 Musyawarah atau rapat yang diadakan setiap minggu dan satu bulan sekali sudah menjadi kebiasaan atau tradisi di SMP Al-Kautsar Tanjungpinang. Direktur M.Supeno mengatakan bahwa pentingnya mengadakan musyawarah atau rapat untuk membahas permasalahan yang ada, terutama yang bersifat kronis. Dalam musyawarah atau rapat biasanya disediakan makanan yang terkadang berupa bakso, makanan ringan dan lainnya yang bisa menjadi penyemangat anggota musyawarah. Direktur AlKautsar dalam setiap rapat sering mengutip salah satu dilakukan agar tidak terjadi konflik yang lebih luas dan tetap menjaga kebersamaan. Pernyataan ini berkorelasi dengan teori Hart dalam Suparman ${ }^{85}$ yang menjelaskan bahwa penyelesaian sengketa atau konflik pada masyarakat atau organisasi yang kondisi masyarakatnya hanya mengenal tingkah laku, tidak mengenal peraturan terperinci, tidak ada diferensiasi dan spesialisasi badan-badan penegak hukum. ini masih sangat sederhana dan didasarkan kekerabatan, negosiasi dan kompromi. Sehingga dapat dijelaskan bahwa antara teori dengan penuturan beberapa peserta didik dan direktur SMP Al-Kautsar sudah cukup sesuai.

\section{J. Kedisiplinan Para Pendidik di SMP Al- Kautsar}

Disiplin adalah mematuhi semua peraturan yang berlaku atau melaksanakan tugas sesuai dengan ketentuan yang telah ditetapkan. ${ }^{86}$ Disiplin kerja pendidik yang terabaikan akan menjadi budaya kerja yang buruk sehingga menurunkan kinerja pendidik dalam menyelenggarakan proses pendidikan. $^{87}$

Sedangkan mengenai kedisiplinan para pendidik di SMP Al-Kautsar, peneliti ketika wawancara dengan Yogi Aprizon, salah satu pendidik mengatakan:

"Ada beberapa guru memang yang datang terlambat ngajar, gak tahu juga sudah diperingatkan tetap datang

ayat Al-Qur'an yang menekankan pentingnya musyawarah dalam memecahkan permasalahan. Tidak jarang dalam rapat terjadi perdebatan antara kepala sekolah dan para pendidik dalam mempertahankan argumennya.

${ }^{85}$ Eman Suparman, Arbitrase..., hlm. 35.

${ }^{86}$ Kompri, Manajemen Sekolah Orientasi

Kemandirian Kepala Sekolah, cet.ke-1, (Yokyakarta: Pustaka Pelajar, 2015), hlm. 199.

${ }^{87}$ Barnawi dan Mohammad Arifin, Kinerja Guru Profesional, (Yokyakarta: AR-RUZZ MEDIA, 2014), hlm. 109. 
terlambat datang, kadang tak pakai seragam pula, padahal diwajibkan pake sepatu, kaos kaki, lengan panjang, dasi, tapi peraturan belum tertulis kadang diingatkan kepala sekolah nanti nurut besoknya gak lagi, mungkin bahasanya kepala sekolah kurang pas, ketika menegur guru haruslah dengan bahasa yang halus, ya lebih kesadaran aja yang perlu ditingkatkan, guru piket sekarang juga tak aktif, kesadaran kurang, guru ini kan panutannya dari anak-anak kalau gurunya disiplin otomatis anak anaknya mengikuti kalau semua mendukung insyaalloh akan terealisasi". ${ }^{88}$

Berdasarkan wawancara di atas didapat informasi bahwa ada beberapa pendidik yang kesadarannya kurang dan perlu ditingkatkan tentang kedisiplinan. Di samping itu selayaknya kepala sekolah memakai bahasa yang baik dan halus dalam mengingatkan dan menegur bawahannya.

Masih berkaitan dengan kedisiplinan para pendidik di SMP AlKautsar, Vina Suroya kepala sekolah SMP Al-Kautsar ketika wawancara dengan peneliti mengatakan:

"Kadang saya merasa jenuh dan malas mengingatkan terus guru-guru, dingatkan kadang besoknya nurut besoknya balik lagi, harus ada keputusan tegas, pusing sendiri ngingatkan masih sering terlambat, girohnya macam ga ada gimana, kadang disuruh ngantor gak ngantor,

88 Wawancara dengan Yogi Aprizon, pendidik di SMP Al-Kautsar, tanggal 26 Pebruari 2018 siang-siang ada guru diniyah pakai sandal diingatkan tetap saja." 89

Berdasarkan hasil wawancara di atas, didapat informasi bahwa harus ada keputusan tegas terkait kedisiplinan para pendidik. Kedisiplinan para pendidik di SMP Al-Kautsar masih sebatas peraturan yang menjadi slogan dari sekolahan. 90 Disiplin pada hakekatnya adalah kemampuan untuk mengendalikan diri dalam bentuk tidak melakukan suatu tindakan yang tidak sesuai dan bertentangan dengan sesuatu yang telah ditetapkan. ${ }^{91}$ Disiplin dapat dibedakan menjadi dua bagian, yaitu disiplin atas kesadaran diri, dan disiplin yang diperintahkan.

Masih menurut Kompri, pendidik tanpa penerapan disiplin yang sesuai di sekolah maka tujuan pendidikan dan pengajaran cenderung tidak akan tercapai. Oleh karena itu, para pendidik dan pegawai lainnya yang dipimpin oleh kepala sekolah, menciptakan berbagai peraturan yang diterapkan untuk para guru dan pegawai lainnya. ${ }^{92}$

Dengan adanya disiplin kerja pendidik, kegiatan sekolah dapat

${ }^{89}$ Wawancara dengan Vina Soraya, kepala sekolah SMP Al-Kautsar, tanggal 10 Pebruari 2018.

${ }^{90}$ Beberapa pendidik yang datang terlambat mengajar di SMP Al-Kautsar menjadi sebuah pemandangan yang biasa. Beberapa pendidik sering terlihat memakai seragam lengan pendek dan memakai sandal ketika mengajar, padahal peraturan dari yayasan diwajibkan memakai lengan panjang dan sepatu. Hal ini menjadi contoh yang kurang baik bagi peserta didik yang cenderung meniru tingkah laku dari pendidik. Selama belum ada peraturan dan sangsi yang tegas dari yayasan, kasus ini akan berjalan terus dan menjadi hal yang lumrah dikalangan pendidik.

${ }^{91}$ Samion ar, "Pengaruh Disiplin Mengajar Guru Terhadap Efektifitas Belajar Siswa", dalam Jurnal Mimbar Pendidikan, Vol 3, Nomor 1, Oktober 2006, hlm. 64.

${ }^{92}$ Kompri, Manajemen Sekolah..., hlm. 201. 
dilaksanakan dengan tertib dan lancar. Pembelajaran dapat dilaksanakan dengan tepat waktu sehingga target kurikulum dapat tercapai. ${ }^{93}$

Disiplin pada pendidik sangat penting untuk dikembangkan karena tidak hanya bermanfaat bagi sekolah, tetapi juga bagi pendidik itu sendiri. Dengan adanya disiplin kerja pendidik, kegiatan sekolah dapat dilaksanakan dengan tertib dan lancar. Pembelajaran dapat dilaksanakan dengan tepat waktu sehingga target kurikulum dapat tercapai. ${ }^{94}$

\section{K. Penutup}

Berdasarkan dari hasil penelitian dan pembahasan yang telah dipaparkan pada bab-bab sebelumnya, yang intinya merujuk secara keseluruhan kepada permasalahan dan tujuan penelitian, dapat disimpulkan sebagai berikut:

1. Konflik di SMP Al-Kautsar terjadi berkaitan dengan beberapa kebijakan dari kepala sekolah. Konflik yang terjadi di SMP Al-Kautsar dapat diidentifikasi di antaranya pengambilan beberapa kebijakan yang dilakukan oleh kepala sekolah tanpa ada komunikasi dan koordinasi terlebih dahulu kepada para pendidik. Kesadaran para pendidik akan pentingnya mentaati tata tertib yang sudah ditetapkan oleh pihak sekolah harus ditingkatkan.

2. Manajemen konflik kepemimpinan kepala sekolah di SMP Al-Kautsar Tanjungpinang dengan melakukan sosialisasi, koordinasi dan komunikasi dengan bawahan. Sedangkan resolusi konflik dengan menggunakan kompromi, negosiasi dan komunikasi antara kepala

${ }^{93}$ Barnawi dan Mohammad Arifin, Kinerja Guru Profesional..., hlm. 109.

${ }^{94}$ Ibid..., hlm. 109.

Ainur Rofiq sekolah dan para pendidik. Ketika konflik masih belum bisa diselesaikan, maka pihak ketiga sebagai mediator yang berperan penting dalam manajemen konflik.

\section{DAFTAR PUSTAKA}

Danim, Sudarwan, Suparno, Manajemen Kepemimpinan dan Kepemimpinan Transformasional Kekepalasekolahan: Visi dan Strategi Sukses Era Teknologi, Situasi Krisis, dan Internasionalisasi Pendidikan, Jakarta: Jakarta: PT Rineka Cipta, 2009.

Departemen Agama Republik Indonesia, AlQur'an dan Terjemahnya, Jakarta: Syamil Al-Qur'an, 2013.

Fahmi, Irham, Perilaku Organisasi Teori, Aplikasi, dan Kasus, Bandung: AlfaBeta, 2014

Kompri, Manajemen Sekolah Orientasi Kemandirian Kepala Sekolah, Cet.1, Yokyakarta: Pustaka Pelajar, 2015.

Kurniadin, Didin dan Imam Machali, Manajemen Pendidikan Konsep dan Pengelolaan Pendidikan, Yokyakarta: Ar-Ruzz Media, 2012.

Moleong, Lexy J, Metodologi Penelitian Kualitatif, Bandung: PT Remaja Rosdakarya, 2005.

Mulyasa, Menjadi Kepala Sekolah Profesional Dalam Konteks menyukseskan MBS dan KBK, Bandung: PT Remaja Rosdakarya, 2005.

Mulyono, Manajemen Administrasi dan Organisasi Pendidikan, Yokyakarta: Ar-Ruzz Media, 2008. 
Qomar, Mujamil, Manajemen Pendidikan Islam Strategi Baru pengelolaan Lembaga Pendidikan Islam, ttp: Erlangga, t.t.

Santosa, Edi, dan Lilin Budiati, Manajemen Konflik, Tangerang: Universitas Terbuka, 2014.

Satopo, Hendyat, Perilaku Organisasi:Teori Dan Praktike Dibidang Pendidikan, Bandung: Rosdakarya dan UNM, 2012.

Sedarmayanti, Restrukturisasi dan Pemberdayaan Organisasi, Bandung: PT Refika Aditama, 2014.

Siagian, Sondang P, Teori dan Praktek Kepemimpinan, Cet. 6, Jakarta: PT Rineka Cipta, 2010.

Sudjana, Nana, Penelitian dan Penelitian Pendidikan, Bandung: Sinar Baru, 2000.

Sugiono, Metode Penelitian Pendidikan, Pendekatan Kuantitatif, Kualitatif, dan R\&D, Bandung: Alfabeta, 2010.

Suparman, Eman, Arbitrase dan Dilema Penegakan Keadilan, Jakarta: PT Fikahati Kristiandi, 2012.

Suwandi, dan Basrowi, Memahami Penelitian Kualitatif, Jakarta: Rineka Cipta, 2008.

Syakur, Fatah, Manajemen Pendidikan Berbasis Pada Madrasah, Semarang: PT Pustaka Rizki Putra, 2011.

Tika, Moh Pabundu, Budaya Organisasi dan Peningkatan Kinerja Perusahaan, Jakarta: Bumi Aksara, 2006.
Usman, Husaini, Manajemen Teori, Praktik, dan Riset Pendidikan,(Jakarta: Remaja Rosdakarya, 2014.

Winardi, Manajemen Konflik, ,Konflik Perubahan dan Pengembangan, Bandung: Mandar Maju, 1994.

Wirawan, Konflik Dan Manajemen Konflik, Teori, Aplikasi, dan Penelitian, Jakarta: Salemba Humanika, 2013.

\section{JURNAL/ARTIKEL:}

Ahmad Muslim, "Manajemen Konflik Interpersonal di Sekolah", dalam Jurnal Paedogogy, Fakultas Ilmu Pendidikan IKIP Mataram, Vol. 1, Nomor 2, Oktober 2014.

Budi Sri Supeni, "Pengaruh TQM dan Kedisiplinan Guru" dalam Jurnal Akuntasi dan Ilmu Pendidikan, Vol.3, Nomor 2, Oktober 2014.

Hanatidah Altar, "Upaya Meningkatkan Kedisiplinan Guru dalam Kehadiran di Kelas Melalui Keteladanan", dalam Jurnal Bionature, Vol.15, Nomor 1, April 2014.

Leny Marlina, "Tipe-Tipe Kepemimpinan dalam Manajemen Pendidikan", dalam Jurnal Ta'dib, Fakultas Tarbiyah dan Keguruan, Vol. 18, Nomor 2, November 2013.

Sri Rahayu, "Kepemimpinan Sekolah dan Kedisiplinan Guru SMPN Kota Surakarta", dalam Jurnal Manajemen Pendidikan, Magister Manajemen Pendidikan UMS, Vol.9, Nomor 2, Juli 2014. 
Sukarsih, "Meningkatkan Kedisiplinan Guru SMPN 8 Bontang", dalam Jurnal Ilmu Pendidikan,Cendikia, Vol.9, Nomor 1, April 2015.

Yani Tri Wijayanti, Asep Suryana, "Manajemen Konflik Organisasi dalam Perspektif Islam”, dalam Jurnal komunikasi Profetik, Vol. 8, Nomor1, April 2015. 